\title{
The Impact of Persuasive Language on Ideology Perceived in Translated Children's Literature: A Case Study
}

\author{
Rahil Akbarpour \\ Department of Translation Studies, Fars Science and Research Branch, Islamic Azad University \\ PO box 71849-66958, Shiraz, Iran
}

Received: 28-08- 2013

Accepted: 30-09- 2013

Published: 15-10- 2013

doi:10.7575/aiac.ijclts.v.1n.3p. 26

URL: http://dx.doi.org/10.7575/aiac.ijclts.v.1n.3p. 26

\begin{abstract}
This study was conducted to examine the impact of persuasive language on ideology perceived by children while reading translated children's books. To do so, the author studied the ideological manipulations made in children's literature translation (ChLT) through analyzing the two abridged Persian translations of Mark Twain's The Adventures of Tom Sawyer. The researcher also was looking for major strategies used by the translators to reinforce the ideological attitudes of the recipients. In this regard, a model of critical discourse analysis (CDA), that of Fairclough, was used to analyze the translations in terms of their vocabulary. The model introduces three values of words, namely, experiential, relational, and expressive. Making use of the expressive value, the researcher found that the translators of the novel tried to fit the translated novel into the Iranian culture, using modification, addition, and deletion strategies. Those strategies were determining factors of the ideologies perceived by the young readers.
\end{abstract}

Keywords: ideology, persuasive language, children's literature translation, manipulation, critical discourse analysis, translation strategy

\section{Introduction}

These days, there is a tendency to translate adult books, especially classics, for children and adolescents. In this respect, many classic books, such as Defoe's Robinson Crusoe, Mark Twain's The Adventures of Tom Sawyer, and Charles Dickens's Oliver Twist, have been also abridged while translated for children. The original books are abridged for a variety of reasons that are related to didactic, ideological, cultural, sociological, psychological, and cognitive aspects of children's literature (ChL). In addition, many classic books that were originally intended for adults are now commonly thought of as works for children. Mark Twain's The Adventures of Tom Sawyer was originally intended for an adult audience. However, today it is widely read as a part of children's school curriculum in the United States. Recently, it has also been translated into Persian for children.

Some researchers describe translating $\mathrm{ChL}$ as a means of cross-cultural communication involving the cultures of both children and adults. This is mainly because adults communicate with children through literature (Oittinnen, 2000). On the other hand, children are introduced to literature read by people of their age in other countries and are exposed to domains of other lives and cultures through which they begin to understand and accept each other as being unique and having different literary and cultural experiences (Vandergrift, 1997). However, translating ChL might cause challenges due to different morals, ideologies and customs of two distinct cultures.

Roman Alvarez and Carmen-Africa Vidal (1996) point out that:

Behind every one of the translator's selections, as what to add, what to leave out, which words to choose and how to place them, there is a voluntary act that reveals his history and the sociopolitical milieu that surrounds him; in other words, his own culture and ideology. (p. 5)

Therefore, translation is influenced by translators' own cultural values and ideology that causes them to manipulate the source text.

The matter of ideology in Translation Studies is closely related to translation norms, translation strategies, and the belief that the translators' decision-making is norm-governed. Ideology is a principal issue in the field of ChLT, and is closely related to censorship and manipulation (Xeni, 2007). On censorship and manipulation in ChLT, Shavit (1986) argues that "censorship often justifies on pedagogical grounds or resulting from children's assumed incapability of understanding" (p. 112). She explains that because of the peripheral position of ChLT in the literary system, the translator is authorized to "manipulate the text in various ways by changing, enlarging or abridging or by deleting or adding to it" (p. 112).

Moreover, according to Stephens (1992), every book has an implicit ideology, which is usually expressed through beliefs and values taken for granted in society. Accordingly, a translated book also may have an implicit ideology in the form of beliefs and values of the target society. In this regard, translators play a crucial role in representing the beliefs and values of the target people through deciding which lexical and grammatical items to be used.

In this respect, the author decided to examine the ideological manipulations made in two abridged Persian translations of Mark Twain's The Adventures of Tom Sawyer in order to find out if the translators could render the novel in a way preserving, even reinforcing, Iranian children's ideological attitudes. The author also explored the prevalent strategies 
used by the translators to reinforce recipients' ideological attitudes.

\section{Review of Literature}

\subsection{Children's literature}

There are some definitions with nuances for what ChL is. Education Encyclopedia (2008) defines ChL as:

Any literature that is enjoyed by children. More specifically, ChL comprises those books written and published for young people who are not yet interested in adult literature or who may not possess the reading skills or developmental understandings necessary for its perusal.

Oittinen (2000) defines ChL as "the literature read silently by children and aloud to them" (p. 6). She (2000) adds that $\mathrm{ChL}$ can be seen both as literature produced for children and as literature read by children.

The broadest definition of children's literature applies to books that are actually selected and read by children. Children select many books, such as comics or literary classics.

There are various age categorizations with different number of subdivisions for $\mathrm{ChL}$. ChL is an age category opposite adult literature, but it is subdivided further due to the diverse interests of children age 0-18, including picture books for ages $0-5$; early-reader books for children age 5-7; chapter books that are in turn composed of short chapter books for children ages 7-9 and longer chapter books for children ages 9-12; and young-adult fiction for children age 12-18 ("By age category," n.d.). There is not a clear-cut standard for specifying these divisions, as books near a borderline may be classified either in the previous or next subdivision.

\subsubsection{The Role and the Position of Children's literature}

Although ChL plays multiple roles as an educational, social, and ideological instrument, it is generally thought of as a peripheral and uninteresting area of study. Besides being entertainment and help developing children's reading skills, it also provides world knowledge, ideas, values, and accepted behavior to children. Therefore, while translating children's books, various adjustments may be required in order to accomplish the notions of what is good and appropriate for children and also what is regarded as the suitable level of comprehensibility in a given target culture (Puurtinen, 1998).

Writers can help create and maintain beliefs, values and relations of power by the language they use such as the lexical and syntactic choices. Syntactic structures, such as nominalization, passivisation, and theme-rheme structures, can reflect a worldview through creating a particular perspective on the events, which the writer does not necessarily intend to do (Puurtinen, 1998).

In this respect, the language of children's literary and nonliterary texts is a very powerful socializing instrument, as Halliday (1978) emphasizes that children receive information about customs, hierarchies and attitudes through language. Therefore, the language of literature can promote and reinforce the adoption of these customs and so forth.

Polysystem theory (Even-Zohar, 1990) believes that translated literature is usually in a peripheral position and thus is loyal to norms and models that have been already established in the literary system. As children's literature tends to be peripheral, translations in this area might most adhere to conventions and, consequently, to the target norms.

Even-Zohar (1990) investigates how literature and translation act in specific contexts or systems. The polysystem theory covers all major and minor literary systems within a society. Every literary polysystem consists of a number of subsystems that are hierarchically arranged. The closer to periphery a subsystem is, the lower its cultural status within the entire system. A subsystem in the centre represents a significant part of a country's literature, and a subsystem in the periphery represents a less influential part. ChL constitutes a part of the literary system. It usually maintains a peripheral position in the literary polysystem, with low cultural status.

\subsection{Children's literature Translation}

ChLT is an almost new area within Translation Studies. Scholars became interested in ChLT when the demand for reading books of other parts of the world, especially of neighbors, began (Hunt \& Bannister Ray, 2004). The demand led to an approach toward ChLT in which the focus was on the child reader.

What has caused the promotion of interest and increase in number of publications in ChLT? In this regard, Tabbert (2002) introduced several factors as follows:

- The belief that the books translated for children build bridges between different cultures.

- The text-specific challenges posed by children's books to translators, such as the interaction between picture and words in picture books, playful use of language, dialect, register, names, cultural references, and so forth.

- The polysystem theory that puts $\mathrm{ChL}$ in a peripheral position of the literary system.

- The age-specific addressees of ChL, who are children with imperfect linguistic competence and limited world knowledge.

ChLT plays some general roles known as didactic or pedagogical, cultural-sociological, psychological, cognitive, and academic aspects in order to perform its mission. The didactic or pedagogical aspect has attracted most attention of researchers and critics. Many people accept that literature, either original or translated, is the best way to stimulate the world and surroundings of children (Wells, 1986).

ChLT has cultural-sociological objectives besides the didactic objective. According to Xeni (2007; 2006e), through literature, cultural content is transmitted and the world is understood more efficiently. Translating children's books from other languages increases number of literary works for young people and spreads universality of human experience. ChLT can be looked at as an international phenomenon because it can go all over the world and cross the linguistic and 
cultural borders, and it can bring a new life to world literature by establishing universal communications (Bassnett, 1993; O’Sullivan, 2005).

In respect to the cognitive aspect of ChLT, children and young adults understand new information easier when it is told through stories (Wells, 1986). When children become interested in reading translated books from other cultures, they try to understand the meaning of those books by activating their cognitive skills like thinking, analyzing, comparing, and so on. Therefore, the cognitive aspect is necessary to reach the cultural-sociological objectives.

On the academic aspect, Fernandez Lopez (as cited in Lathey, 2006) believes that ChL and Translation Studies scientific disciplines also have made scholars pay attention to ChLT because new techniques and subjects have emerged from those disciplines. In the light of academic aspect, issues of ideology and translator's behavior came to Translation Studies.

Some of the prominent theorists who have tried to theorize ChLT are Itamar Even-Zohar, Zohar Shavit, Hans Vermeer, and Katharina Reiss. The researcher will briefly discuss their theories related to ChLT.

Based on the polysystem theory introduced by Even-Zohar, similar to ChL, ChLT has a marginal position in the literary system and has little influence. Following Even-Zohar, Shavit (1981) developed the polysystem theory and applied it to ChLT. Shavit (1981) explains that marginal position of ChL elucidates manipulations that are made on translated texts for children. For instance, changing text genre in order to adapt it to superior models in the target language may disobey the integrity and complexity of the text and ideological and stylistic adaptation.

Vermeer and Reiss (as cited in Munday, 2006) are the two functionalists who developed the skopos (purpose) theory, which has significant applications to ChLT. Considering skopos as the most important criterion in any translation that determines the function of the translation in the target culture, these theorists place the young reader in the central position. So, in translating for children, the translator is free from the obligations to recreate the source text in the target culture the translator has a higher status (Thomson-Wohlgemuth, 1998).

Ritta Oittinen, Emer O’Sullivan, and Tina Puurtinen are some important researchers in ChLT. These researchers investigate issues associated with translation norms and the function of translated ChL, readability of translations in the sense of translation for reading aloud, comparative ChL, child reader, and the child-text interaction (Fornalczyk, 2007).

\subsection{Ideology and Translation}

There are so many definitions for the notion of ideology. Mason (1994) suggests that ideology is a "set of beliefs and values which inform an individual's or institution's view of the world and assist their interpretation of events, facts, etc" (p. 25). Hatim (2000) defines ideology as "a body of ideas which reflects the beliefs and interests of an individual, a group of individuals, a societal institution, and so forth, and which ultimately finds expression in language" (p. 218). Therefore, it can be argued that ideology is a set of beliefs, ideas, interests, and attitudes that are accepted by an individual, a group of individuals, institutions, and so forth, and is sometimes realized as culture.

Van Dijk (2005), who investigates in the fields of discourse analysis and CDA, argues, "Much of our discourse expresses ideologically based opinions" (p. 9). Thus, a comprehensive analysis of the discursive expressions provides fundamental guidelines about the prevalence of ideology in language. According to Hatim (2000), this analysis can be done at different levels including the grammatical level and the lexical level. Therefore, ideology plays an important role in decision-making process undertaken by translators.

According to Schaffner (2003), translation is a matter of ideological choices besides the linguistic choices. A source text is selected according to the target readers' interests as well as their ideological, social, and cultural values. In this regard, the lexical and grammatical choices are exploited in order to show the ideological aspects of a group of people.

Kress and Hodge (1993) discuss the relationship between language and ideology in a simple way. They argue that language is both an instrument of control and an instrument of communication. Linguistic forms can reflect significance of an issue or, otherwise, distort it. Therefore, readers and hearers can be either manipulated or informed. A political sense of language argues that language is ideological because it includes a systematic distortion in the service of class interest.

As understood from Kress and Hodge (1993), they believe that ideological attitudes can be shown through lexical and grammatical choices, that is, linguistic forms. In this respect, translators can give significance to an attitude or belief, or otherwise, underestimate it. Therefore, through translation, the content of a source book may be exposed to several manipulations whose objective is usually to adapt the book to the target recipients' interests, beliefs, and values. Moreover, Kress and Hodge (1993) argue that language in its ideological sense relates to power and makes use of systematic distortions. As ideologies function in language in a form of power relations, translators must aware of these ideologies while translating one language to another language. Therefore, translators who translate texts from a culture that is far distinct from their own culture should be more careful about the ideologies of both the source language and the target language.

\subsection{Ideology and Critical Discourse Analysis}

Critical discourse analysis (CDA) is a rather new discipline in linguistics. Critical Linguistics and CDA were used interchangeably in the past. However, it seems that the latter has been recently preferred and has been applied to refer to the theory that had been introduced as the Critical Discourse (Fairclough \& Wodak, 1997).

CDA regards language as a social phenomenon. Individuals and social groups have meanings, values, and concepts that are defined in language in systematic ways. In CDA, texts are considered as the relevant units of language in communications; readers and listeners are not passive recipients in their relation to texts; there are similarities between the language of science and the language of institutions; and so on (Kress, 1989). Nevertheless, a clearer and more 
general approach to CDA can be found in the work of Fairclough and Wodak (1997). According to them, CDA regards language as a social practice and takes into account the context of language in use.

Van Dijk, in his paper Multidisciplinary CDA: a plea for diversity (collected by Wodak \& Meyer, 2005) argues that CDA "focuses on social problems, and especially on the role of discourse in the production and reproduction of power abuse or domination" (p. 96).

As ideology is expressed by means of language, the ways in which ideological concepts are embedded in language are included in the domain of CDA (Sertkan, 2007). In this regard, Puurtinen (2000) explains, "CDA aims at revealing how ideology affects linguistic choices made by a text producer and how language can be used to maintain, reinforce or challenge ideologies" (P. 178).

Based on the above quotation, the grammatical and lexical choices made by text producers, such as translators and authors, are not accidental. Moreover, these linguistic choices have an underlying ideology representing the ideological dispositions of the text producer. CDA conveys a framework within which these ideological dispositions and the ways of constructing and enhancing them are identified. In this regard, models of CDA including that of Fairclough help analysts to detect the linguistic expressions of ideology in a text.

Calzada-Perez (2003) also believes that the primary aim of CDA is to reveal the ideological forces underlying communicative exchanges such as translating. In this respect, CDA can be used as a methodological tool in analysis of a text in order to uncover the ideological attitudes of the text producer.

\subsection{Some Related Studies}

Zeinab Hussein Taha Khwira (2010) performed a study on the strategies and motivations in children's literature translation, in Palestine. She analyzed three translations of Defoe's Robinson Crusoe in order to highlight mistranslations and likely breakdowns caused by cultural and ideological differences among Arab and foreign cultures. She tested extracts of the translations and a number of questions related to the ideologies presented in those extracts on children aged 14-16. She concluded that the strategies of translation influenced the children's perception of the text and characters largely.

Sertkan (2007) carried out a research on ideology of the lexical choices in Turkish translations of Oliver Twist, using Fairclough's model of CDA. In analysis of the novel and its translations, Sertkan (2007) concluded that CDA offered a valuable framework that reveal the ideological content and the ways in which ideology is expressed and reinforced.

Minga (2005) performed a study in Africa, analyzed the translations of children's books of an author named Ngugi, using a CDA model of Fairclough. The study investigated whether an approach taking into consideration the ideological issues in translation was most appropriate in translating the Ngugi's children books for Francophone young readers. Translators of different origins had carried out the selected translations in different sociocultural contexts. Minga found that specific ideological and social factors affected the translators, resulting in different translations.

\section{Objectives and Research Questions}

As Fairclough puts forth, the expressive value of words tends to persuade others to believe something, mostly an idea. Therefore, expressive values can be demonstrated through persuasive language in various ways, spoken or written. Translators are among the agents who may use the expressive words to enhance an idea and reorient a text toward specific ideologies. In this respect, the author aimed to answer the following questions:

1. Were the translators of The Adventures of Tom Sawyer successful in making use of expressive values of words in order to reorient the translations toward target readers' ideological attitudes, and to what extent?

2. Is there any prevalent strategy used by the translators of the novel in highlighting those ideological attitudes?

\section{Materials and Methods}

In this qualitative empirical study, the two abridged translations of Mark Twain's The Adventures of Tom Sawyer by Soleimani and Modarres Sadeghi, both published in 2009 in Tehran, Iran, were analyzed to find the strategies, if any, taken by the translators in making use of the persuasive language to reinforce the ideological attitudes of Iranian children.

To do so, the source text and its two abridged translations were analyzed and compared through the following steps:

- The source text and the two translations were read carefully.

- Lexical items (words, phrases, and expressions) that sounded different were extracted from the translations and paired with the corresponding ones in the source text. In total, eight extracts were selected purposefully. This method could help identify the alterations to the source text, that is, additions, deletions, and modifications made by the translators.

- The alterations that had been made in the translations of the same lexical items were compared together in order to find distinct strategies, if any, used by the translators.

- The obtained results were analyzed using descriptive statistics in SPSS software.

In this study, the author applied CDA as a methodological tool for the identification of the manipulations performed to highlight the ideological attitudes of the target readers and also to deal with probable ideological breakdowns. In this respect, Fairclough's method of CDA will be used. Fairclough (2001) in his book Language and Power devotes a chapter to describe one method of CDA. He states ten questions and their subquestions based on the three categories of vocabulary, grammar, and textual structure, which are important to critically analyzing any discourse. The category of 
vocabulary consists of four main questions about experiential values, relational values, and expressive values of words; and metaphors. In this analysis, the author focused on the expressive values of words.

According to Fairclough (2001), expressive values imply how the creator of the text relates to the reality it is discussing (Fairclough, 2001, p. 93). As Fairclough defines it, expressive value is connected with "subjects and social identities" (2001, p. 93). He also points out that "the expressive value of words has always been a central concern for those interested in persuasive language" (2001, p. 99).

\section{Results and Discussion}

\subsection{Results of the Analysis}

In the case of the expressive values of words, eight extracts were identified in this study. In all the extracts, except one, the translators have made use of the persuasive language to show the magnitude and glory of God and that God is the only source of power one can believe in. Generally, the translators have highlighted the religious beliefs of the target people using strategies, including addition, modification, and deletion. It must be noted that any of these strategies may determine the ideologies perceived by the readers. For instance, addition of the word 'xodâ' meaning 'God' to a piece of translation highlighted the religious beliefs of the target community. In another case, the translator has deleted a word of the source text in order to persuade the readers that a harmful habit like smoking was an unpleasant action.

Moreover, the author found out that each translator had treated the text differently, as the second translator has avoided translating most of the extracts. This has resulted to two texts with different form and length. The following examples extracted from different chapters of the novel show the comparison between the source text and the target texts in terms of expressive values.

The abridged translations by Soleimani and Modarres Sadeghi are referred to as target text 1 (TT1) and target text 2 (TT2), respectively. The original extracts are referred to as the source text (ST).

\section{Example 1}

This extract is from chapter one in which Tom eats jam stealthy. Aunt Polly understands it and wants to punish him. However, Tom escapes before she has time to do so. Aunt Polly utters the following statement.

ST: Well-a-well, man that is born of woman is of few days and full of trouble, as the Scripture says, and I reckon it's so.

$$
\text { TT1 خب خود خدا هم توى كتابش مى كويد آدمى كه زن به دنيايش مى آورد كارش توى اين دو روز دنيا فقط عذاب كثيدن است. }
$$

/xob xod-e xodâ ham tu-y-e ketâb-aš miguyad 'âdami ke zan be donya-y-aš mi'âvarad kâraš tu-y-e 'in do ruz-e donya faqat 'azâb-kešidan-ast/.

None :TT2

As seen in the ST, the sentence in boldface does not mention a word meaning God although the word 'scripture' in the خود خدا هم ' ST implies the God's words. However, the first translator has rendered the sentence 'as the scripture says' 'انوى كتابش مى كويد (xod-e xodâ ham tuy-e ketâb-aš miguyad/) meaning that 'God also says in his scripture.' The translator has added the word 'God' to emphasize that God is the source of all truths and beliefs. In other words, the translator wants to persuade the readers that the only source of power and belief is God.

\section{Example 2}

This extract is from chapter six. Tom writes a sentence on his slate and hides it from Becky Thatcher. Becky wants to know what Tom has written on his slate. So, she promises not to tell anyone what he has written if he allows her to see the slate.

ST: "You'll tell."

"No I won't--deed and deed and double deed won't."

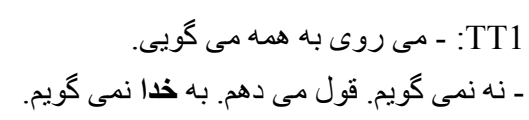

/miravi be hame miguyi/.

/na ne-miguyam/. /qowl midaham/. /be xodâ ne-miguyam/.

None :TT2

In this extract, Becky promises Tom that she never tells anybody what she has seen on Tom's slate. As indicated by the translation, the sentence 'No I won't--deed and deed and double deed won't' has been rendered to ' نه نمى كويم. قول مي دهم 'به خدا نمى كويم (/na ne-miguyam/, /qowl midaham/, /be xodâ ne-miguyam/). The Persian sentence means that 'I swear to God that I won't tell anybody.' According to the ST, Becky does not mention any word meaning 'God.'

It was not necessary to add the sentence 'be xodâ ne-miguyam' to the translation because without this sentence, the content of the ST has been completely transferred into the TT1. However, the first translator has added the word 'خدا' (/xodâ/) meaning 'God' to show that God is the only power human can swear to and rely on. In this respect, the translator has indirectly highlighted the strong belief of the target readers in God in all situations.

\section{Example 3}

The below extract is from chapter nine. Muff Potter and Doctor Robinson grapple each other. Injun Joe kills the doctor with Potter's knife and inculpates Potter for the murder. Now, Potter blames himself for he thinks that he has really killed the doctor. 
ST: "Oh, I didn't know what I was a-doing. I wish I may die this minute if I did.

$$
\text { TT1 اصلاً نفهيدم جى كار دارم مى كنم. خدا مر ا بكثد اكر بخو اهم دروغ بكويم. }
$$

/'asl-an na-fahmidam či kâr dâram mikonam/. /xodâ marâ bekošad 'agar bexâham doruq beguyam/.

$$
\text { TT2 }
$$

/'âxe man 'asl-an ne-mifahmam ke dâram če-kâr mikonam/.

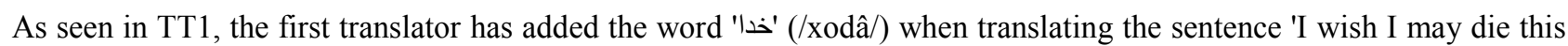
minute if I did.' The English sentence has been rendered to 'خدا مر ا بكثد اكر بخواهم دروغ بكويم' (/xodâ marâ bekošad 'agar bexâham doruq beguyam/) meaning 'God kill me if I lied.' The ST has not mentioned any word in the sense of 'God,' whereas the translator has added it. By use of the word 'God,' the translator wants to emphasize that, the people of the target community believe in God in all aspects of life. In addition, he wants to establish the religious ideas in children, to make them realize how God is significant in the society they live in. The TT1 shows that God is the one who has the power to let people alive or die, and this reminds the readers the religious ideologies of their community. As shown by TT2, the second translator has not translated this sentence.

\section{Example 4}

This example has been extracted from chapter thirteen. Tom and his friends Huck and Joe Harper decide to go to an uninhibited island and become pirates. Each boy chooses a nickname for himself. Red-Handed is the nickname of Huck.

ST: The Red-Handed made no response, being better employed. He had finished gouging out a cob, and now he fitted a weed stem to it, loaded it with tobacco, and was pressing a coal to the charge and blowing a cloud of fragrant smoke--he was in the full bloom of luxurious contentment. The other pirates envied him this majestic vice, and secretly resolved to acquire it shortly.

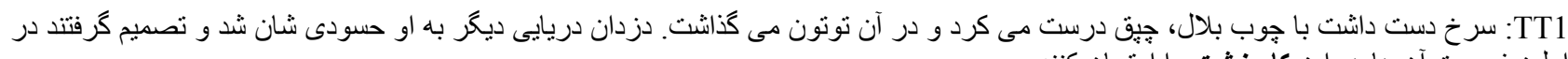

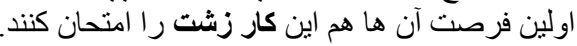

/sorx-dast dâšt bâ čub-e balâl/, /čopoq dorost mikard va dar 'ân tutun migozâšt/. /dozdân-e darya-y-i-e digar be 'u hasudi-y-e-šân šod va tasmim gereftand dar 'avalin forsat 'ân-hâ ham 'in kâr-e zešt râ 'emtehan konand/.

None :TT2

In this example, the phrase 'majestic vice' refers to a fault that is regarded majestic. The fault here is smoking tobacco. Huck, one of the three boys in the uninhibited island, smokes tobacco, and the two other boys envy him and decide to try smoking tobacco betimes. The ST suggests that smoking is a majestic action although it is a fault. However, the first translator has rendered the 'majestic vice' to 'كار زشت' (/kâr-e zešt/) meaning the 'obscene act.' As seen in the translation, the word 'majestic' has not been translated at all. The reason is that the translator wants to show young readers that smoking is considered as an unpleasant act.

The translator has deleted a word of the ST in order to persuade the readers that smoking is not a majestic action, but on the contrary, an unpleasant action.

\section{Example 5}

The below extract is from chapter twenty. Becky Thatcher takes the teacher's book and turns its pages. However, when she wants to close the book, she tears the page she is watching. Tom sees her as she causes the page to be torn. Therefore, Becky gets nervous and fears that Tom will tell the truth to the teacher.

ST: "You ought to be ashamed of yourself, Tom Sawyer; you know you're going to tell on me, and oh, what shall I do, what shall I do! I'll be whipped, and I never was whipped in school."

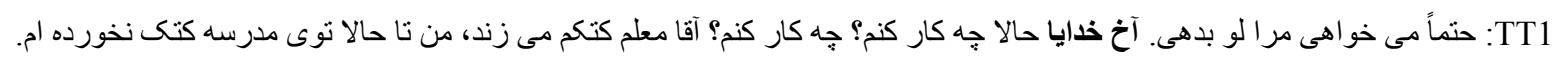

/hatm-an mixâhi marâ lo bedahi/. /'âx xodâ-yâ hâlâ če kâr konam/? /če kâr konam/? /'âqâ mo'allem kotak-am mizanad/, /man tâ hâlâ tu-y-e madrese kotak na-xorde-am/.

None :TT2

As seen in this extract, the interjection of exclamation 'oh' has been rendered to 'خدايا' خآخ' (/'âx xodâ-yâ/) literally meaning 'oh, God.' Obviously, the ST does not have any word in the sense of 'God,' whereas the first translator has added the word 'God' to his translation. In this respect, the translator shows that God is the only power that people can rely on in difficulties. This enhances religious ideologies of the target community in the mind of young readers.

\section{Example 6}

The below extract is from chapter twenty-six. Huck and Tom are in an abandoned house. They are watching two men coming into the house to take their hidden money. The men sleep for a while. Each of them must watch when the other is slept. However, both of them fall asleep until a noise awakes one of them.

ST: Now one snore ceased. Injun Joe sat up, stared around--smiled grimly upon his comrade, whose head was drooping upon his knees--stirred him up with his foot and said: "Here! YOU'RE a watchman, ain't you! All right, though-nothing's happened." 
جر1 صداى خر و يف يكى از مردها قطع شد. جو بلند شد و نشست و نكاهى به اطر افش كرد. بعد لبخن تلخى زد و كفت: "بارك الله! جه نكهبان

خوبى! اما عيب ندارد، جون إنفاقى نيفتاده.

/sedâ-y-e xor-o-pof-e yek-i 'az mard-hâ qat' šod/. /jow boland šod-o nešast va negâh-i be 'atrâf-aš kard/. /ba'd labxand-e talx-i zad-o goft/: /bârek-allâh/! /če negahbân-e xub-i/! /ammâ 'eyb na-darad/, /čon 'etefâq-i na-y-oftade/.

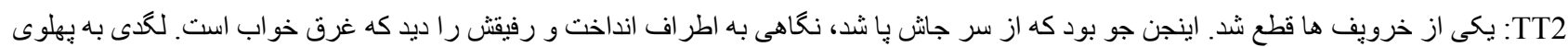

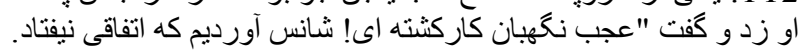

/yek-i 'az xor-o-pof-hâ qat' šod/. /'injen jow bud ke 'az sar-e jâš pâ šod/, /negâh-i be 'atrâf 'andâxt va rafiq-aš râ did ke qarq-e xâb-ast/. /lagad-i be pahlu-y-e 'u zad va goft 'ajab negahbân-e kâr-košt-e-i/! /šâns 'âvardim ke 'etefâq-i na-yoftad/.

In this example, the word of exclamation 'Here!' has been rendered to '!لهارك (ل) (/bârek-allâh/) literally meaning 'God bless you!' Actually, the term 'bârek-allâh!' is an Arabic word used also by Farsi speakers to admire someone. In this example, both the word 'Here!' in the sense of 'Hey!' and its translation 'bârek-allâh!' have been used ironically to squib the slept man that what a good watchman he is. There are some translations for the word 'Here!' including '!بينو' (/'ino bebin/) meaning 'Look at him!' and 'هى' (هل/hey/) meaning 'Hey!' that the translator could have used instead of 'bârek-allâh!' Anyway, the translator has used the word 'bârek-allâh!' although it does not mean 'Here!' The use of 'bârek-allâh!' in this context shows the strong religious beliefs of the target readers because it refers to the fact that God is the sole source of blessing. In respect to the TT2, the word 'Here!' has not been translated.

\section{Example 7}

This example is from chapter thirty-one. Tom and Becky go to a picnic with their classmates. The students go on a hike in a cave and get out of the cave when the time of picnic is finished. Now, they must return to the village. However, Tom and Becky get lost in the murky aisles of the cave.

ST: "Well. But I hope we won't get lost. It would be so awful!" and the girl shuddered at the thought of the dreadful possibilities.

$$
\text { TT1 باشند، اما خدا كند كم نشويم. اكر كم شويم بيجاره مى شويم. }
$$$$
\text { و از اين فكر لرزيد. }
$$

/bâšad/, /ammâ xodâ konad gom na-šavim/. /'agar gom šavim bičâre mišavim/.

/va 'az 'in fekr larzid/.

$$
\begin{aligned}
& \text { TT2 }
\end{aligned}
$$

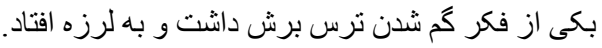

/'omidvâram ke gom na-šavim/. /xeyli bad-jur-i-y-e/.

/beki 'az fekr-e gom šodan tars bar-aš dâšt va be larze 'oftad/.

In this example, the first translator has rendered the sentence 'I hope' to 'خدا كند' (/xodâ konad/). The sentence 'xodâ konad' means 'May God help us,' which actually has the meaning equal to 'I hope.' The second translator has rendered the sentence 'I hope' to 'اميدوارم' (/'omidvâram/), which is the exact meaning of the English sentence. Although the sentence ' 'omidvâram,' used by the second translator, implies trusting in a superior power, that is, God, it does not suggest the word 'God' explicitly. Both translators have rendered the sentence 'I hope' to its right sense. However, the first translator has chosen to translate the sentence in a way showing that God is the sole source of hope and reinforcing the religious beliefs in the young readers. Therefore, TT1 is found as an example of the expressive value that highlights the young readers' values and beliefs.

\section{Example 8}

This example has been extracted from chapter thirty-three. Tom and Huck find a treasure in the cave. They carry it toward the village. However, on their way to the village, they come across an old man named Jones. The old man requests them to go to Widow Douglass's house.

ST: Huck said with some apprehension--for he was long used to being falsely accused:

"Mr. Jones, we haven't been doing nothing."

$$
\begin{aligned}
& \text { TT1 ولشمان كفت: "مهم نبست. وقتى خانه ى بيوه داكلاس رسيديم خودتان مى فهميد." } \\
& \text { ـآقاى جونز به خدا ما كار بدى نكرديم. }
\end{aligned}
$$

/velšmân goft/: /mohem nist/. /vaqti xâne-y-e bive-y-e dâglâs residim xod-e-tân mifahmid/.

/'âqâ-y-e jownz be xodâ mâ kâr-e bad-i na-kardim/.

None :TT2

As indicated in this extract, the sentence 'Mr. Jones, we haven't been doing nothing' has been translated to 'قاى جونز بكان 'خدا ما كار بدى نكرديم ('âqâ-y-e jownz be xodâ mâ kâr-e bad-i na-kardim/) meaning 'Mr. Jones, we swear to God we did not do anything wrong.' In TT1, the translator has added 'به خدان خدا' (/be xodâ/) in the sense of 'we swear to God,' which clearly does not exist in the ST. In this example, again, the translator represents God as the only source to which people oath and the only source people can believe in. Although the complete content of the ST can be transferred to the target language without adding the notion of 'swear to God,' the addition highlights the strong belief of the target community in God. 


\subsection{Discussion}

According to the examples, the first translator has oriented the meaning of the source text toward the target culture and ideology in a positive way. The extent to which the first translator and the second translator were successful to do so is $100 \%$ and $0 \%$, respectively. In this regard, the first translator has manipulated the source text in order to highlight the target culture and ideologies, especially religious ones. The notions toward which the manipulations have been oriented involve believing in God as the sole source of power, hope, trust, and security. The manipulations were done through additions, modifications, and deletions.

In respect to the second question of this study, the most prevalent strategy used by the first translator to manipulate the text was addition that comprised $62.5 \%$ of the total strategies. The strategies of modification and deletion comprised $25 \%$ and $12.5 \%$, respectively. As discussed earlier, the second translator has translated only two extracts without any orientation toward a specific ideology.

The study by Sertkan (2007) found a result similar to the above result. Sertkan (2007) analyzed five versions of Oliver Twist and found that constant use of lexical items with religious connotation in translation preserves the values, ideas, and beliefs that are current in the readers' mind. In the present study, the translators have also manipulated the original text and emphasized the use of words like 'xodâ' meaning 'God' to highlight the target readers' religious ideologies.

The study by Zeinab Hussein Taha Khwira (2010) also agrees with the results of the present study. The translators of Robinson Crusoe used different strategies such as deletion, addition, and modification in order to fit the original text into the Arab culture. They also revealed that the strategy of translation is a determining factor in the children's understanding of the ideologies and values embedded in the text. As mentioned earlier, translators of The Adventures of Tom Sawyer also has used deletion, addition, and modification strategies in cases that reflected specific ideologies.

The results of Minga's study (2005) on the appropriateness of an approach taking into consideration the ideological issues in translation of Ngugi's children books for Francophone young readers showed that the translated texts read differently from one translator to another. The present study showed that the two translators have provided translations with different form and length.

\section{Conclusion}

Based on the results, the two translators differed in their approach toward the translation of the source text. In this regard, the first translator felt more freedom to manipulate the text in order to reorient the translation toward specific ideologies, mostly religious ones, of the target readers. When adding a notion to a piece of text, it is usually done to give more information, that is, to explicate an issue. On the contrary, deleting a notion from the text means that the translator has decided to give less information or to make something implicit in the text. It can be concluded that the strategies used by translators can determine the ideology perceived by the readers. The ideologies would be impressive through expressive values of words.

In this respect, the act of translation is subject to translators' decision-making, which is in turn influenced by their own cultural values and their ideology, which causes them to manipulate the source text by making some additions, deletions, adaptations, and so on.

In this regard, Shavit (1981) argues that the translator of ChL have great liberties to manipulate the text due to the peripheral position of $\mathrm{ChL}$ in the polysystem. Therefore, the translator may change the text to enhance its moral or educational values, or to adapt to the child's level of understanding. Considering that ChL tends to be peripheral, translations in this area might be most oriented toward conventions and consequently toward the target norms and ideologies.

Children get information about attitudes, customs, and generally cultures of other nations through literary and nonliterary texts. ChL provides world knowledge, ideas, and values besides entertaining and developing children's reading skills. In this regard, writers' use of lexical and grammatical choices contributes to the established values, beliefs, and ideologies.

The translators were successful to highlight the religious beliefs of the Iranians. It shows that the translators were fully aware of the Iranian cultural and ideological constraints governing ChL. It also reveals that the translators' decision for what and how to translate can make a great impression on readers. Through translation, translators can highlight a belief in the target community and make it more influential by applying specific strategies like the strategy of addition, which has been used in the abridged translations of The Adventures of Tom Sawyer. Therefore, translators not only can reduce the negative effect of the ideologies and cultural attitudes of the source community but also can reinforce some ideologies of the target community that has not been mentioned in the source text.

\section{References}

Alvarez, R. \& Carmen-Africa Vidal, M. (1996). Translation, power, subversion. Clevedon: Multilingual Matters.

Bassnett, S. (1993). Comparative literature: A critical introduction. Oxford: Blackwell.

By age category. (n.d.). In Wikipedia. [Online] Available: http://en.wikipedia.org/wiki/Children's literature (May 28, 2011).

Calzada-Perez, M. (Ed.). (2003). Apropos of ideology (pp. 1-22). Manchester: St. Jerome.

Children's literature. (2008). Education Encyclopedia. [Online] Available:

http://www.google.com/search?hl=ar\&q=48.EducationEncyclopedia (Apr. 20, 2011). 
Even-Zohar, I. (1990). Polysystem studies. Tel Aviv: The Porter Institute for Poetics and Semiotics, Tel Aviv University.

Fairclough, N. (2001). Language and power. Pearson Education: London.

Fairclough, N., \& Wodak, R. (1997). Critical discourse analysis. In T. A. van Dijk. Discourse as social interaction. London: Sage.

Fornalczyk, A. (2007). Anthroponym translation in children's literature - early 20th and 21st centuries. Kalbotyra. 57(3). 93-101.

Hatim, B. (2000). Communication across cultures: Translation theory and contrastive text linguistics. University of Exeter Press: Exeter.

Hunt, P. \& Bannister Ray, S. G. (2004). International companion encyclopedia of children's literature. London: Roudledge.

Hussein Taha Khwira, Z. (2010). Strategies and motivations in translated children's literature: Defoe's Robinson Crusoe as a case study. An-Najah National University, Nablus, Palestine.

Kress, G. (1989). Linguistic processes in sociocultural practice (2nd ed.). Oxford University Press.

Kress, G., \& Hodge, R. (1993). Language as ideology. London: Routledge.

Lathey, G. (2006). The translation of children's literature: A reader. Clevedon, Buffalo, Toronto: Multilingual Matters.

Mason, I. (1994). Discourse, ideology and translation. In R. De Beaugrande, A. Shunnag, \& M. Helmy Heliel (Eds.), Language, discourse and translation in the West and Middle East. John Benjamins: Amsterdam and Philadelphia.

Minga, K. J. (2005). Ideology in the French translation of Ngugi Wa Thiong'o's children's books. University of the Witwatersrand, South Africa.

Modarres Sadeghi, J. (2009). The adventures of Tom Sawyer. Tehran: Ketab-e Maryam.

Munday, J. (2006). Translation studies. London: Routledge.

Najafi, A. (1993). Fundamentals of linguistics and its application in Persian language. Tehran: Niloufar.

O’ Sullivan, E. (2005). Comparative children's literature. London: Routledge.

Puurtinen, T. (1998). Syntax, readability and ideology in children's literature. Meta: Translators' Journal. 43(4). 524533.

Puurtinen, T. (2000). Translating linguistic markers of ideology. In A. Chesterman, N. Gallardo San Salvador, \& Y. Gambier (Eds.), Translation in context. (1998). Amsterdam \& Philadelphia: John Benjamins.

Schaffner, C. (2003). Third ways and new centres: Ideological unity or difference? In M. Calzada Perez (Ed.), Apropos of ideology: Translation studies on ideology -- Ideologies in translation studies (pp. 23-41). Manchester: St Jerome.

Sertkan, K. (2007). The ideology of lexical choices in the Turkish translations of Oliver Twist. Department of Translation Studies, Dokuz Eylül University, Turkey.

Shavit, Z. (1981). Translation of children's literature as a function of its position in the literary polysystem. Poetics Today. 2(4). 171-79.

Shavit, Z. (1986). Poetics of children's literature. Athens, Georgia: University of Georgia Press.

Soleimani, M. (2009). Tom Sawyer. Tehran: Ofogh.

Stephens, J. (1992). Language and ideology in children's fiction. White Plains, NY: Longman.

Tabbert, R. (2002). Approaches to the translation of children's literature: A review of critical studies since 1960. Target. 14(2). 303-351.

Thomson-Wohlgemuth, G. (1998). Children's literature and its translation: An overview. MA Thesis, University of Surrey.

Twain, M. (1876). The adventures of Tom Sawyer. [Online] Available: http://www.gutenberg.org/ebooks/74 (June 2, 2011).

Van Dijk, T. A. (2005). Discourse and ideology - A multidisciplinary introduction. [Online] Available: http://www.discourses.org/UnpublishedArticles/Ideology\%20and\%20discourse.pdf (May 15, 2011).

Vandergrift, L. (1997). The comprehension strategies of second language (French) listeners: A descriptive study. Foreign Language Annals. 30(3). 387-409.

Wells, G. (1986). The meaning makers: Children learning language and using language to learn. Portsmouth: Heinemann.

Wodak, R., \& Meyer, M. (2005). Methods of critical discourse analysis. London: Sage.

Xeni, E. (2006e). The Challenges of Translating Humour in Children and Young Adults' Literature as a Cross-Cultural Communication Activity, Translation and Meaning Series. Maastricht School of International Communication, Maastricht (The Netherlands), pp. 357-370.

Xeni, E. (2007). Children's literature in translation. Invited contribution to Translation Studies and Intercultural Communication Joint MA Research Seminar Series 2007-2008, organized by the Translation Studies Graduate Programme University of Edinburgh and the Centre for Translation \& Interpreting Studies in Scotland (CTISS), November 2007, Heriot Watt University, UK. 